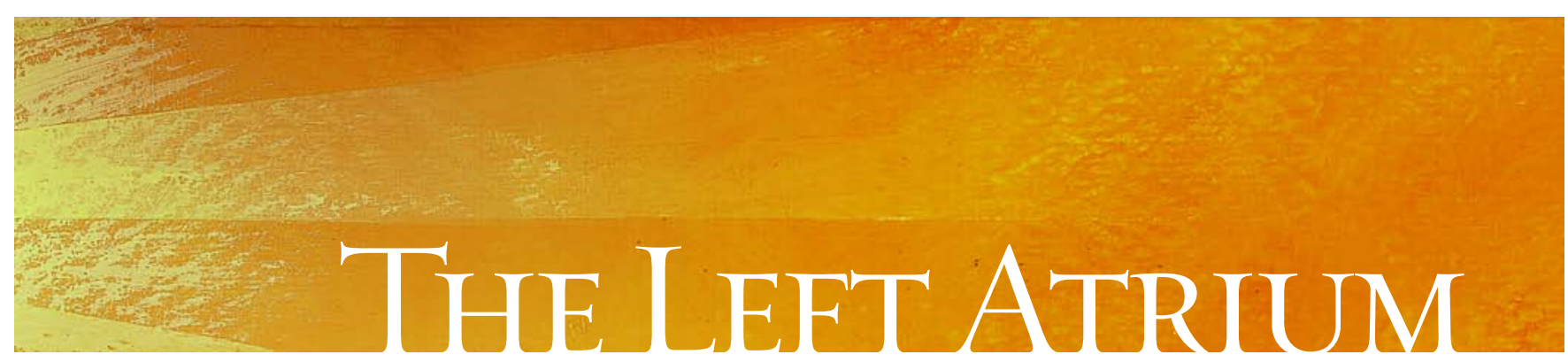

\title{
Whither medical botany?
}

"I wish you had been with us last Tuesday down at the Peat Swamp, there are such splendid flowers down there .... We got the smallest and rarest variety of Ladies Slipper or Indian Moccasin plant ... the most beautiful of all Canadian wild flowers." - "Willie" Osler, aged 17 , after a field trip along the banks of Ontario's Humber River in the spring of 1867.

S ir William Osler is world renowned as an icon of medicine. Yet my first introduction to Osler's writings came not as a medical student, but as a student of botany. A professor presented me with a volume of Osler's essays, encouraging all his botany students to read Aequanimitas, Osler's essay about the virtues of equanimity.

On entering medical school in 1982 , I hoped to parlay my graduate training in botany into instant academic success. I soon realized those hopes were old-fashioned - botany in medical school today is not only unimportant, but is usually considered irrelevant. Yet the histories of medicine and botany have been intertwined since antiquity. From the times of Hippocrates, Aristotle, Theophrastus and Dioscorides, through to the era of herbals and the "Doctrine of Signatures," the historical basis of medical therapeutics is botany. ${ }^{2,3}$ Many of the most influential $\widehat{n}$ naturalists of the scientific age, for example, Carolus Linnaeus (father of the modern classification of plants and animals) and Thomas Huxley (passionate defender of Darwin's theory of evolution), were also trained in medicine. It was only in the last century that botany courses were dropped from medical school curricula.

My awareness of medicine's current indifference to botany increased when I learned that an older William (no longer "Willie"!) Osler professed to a lack of botanical interests. In 1872 , Osler declined the first academic appointment offered to him.

[T] he kind offer made me of the lectureship in Botany [at McGill]. I am afraid you will not be pleased at it, but I really can not do otherwise. If I knew anything of Botany at present; if I had nothing else left to do for two or three years it might be thought of; but as matters stand now I would only make a fool of myself in accepting such a position. I would feel far too keenly the anomalous situation of holding a chair in Botany \& knowing absolutely nothing of the Flora of my native land. ${ }^{4}$

Yet Michael Bliss, in his recent biography of Osler, recounts that Osler's interest in natural history bordered on obsession. The discipline, then called natural philosophy, consisted of 4 subjects: botany, zoology, geology and physics. Osler's favourite classes and favourite instructors were those of natural philosophy. ${ }^{1}$ Osler's first scientific paper was on taxonomy of freshwater diatoms, published in 1870 when he was 20 years old, and the first society to elect Osler a member was the Montreal Natural History Society. Decades later, the final society to elect Osler a member was Oxford's Ashmolean Natural History Society. In I9I9, as president of the Ashmolean Society, he prepared an address on William Withering, the British botanist known in medical circles as the physician who introduced digitalis leaf for the treatment of

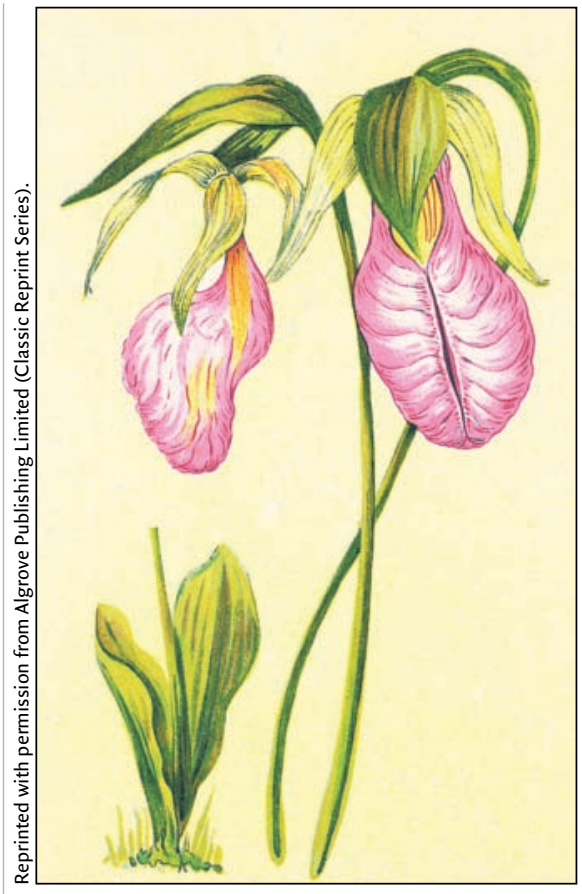

Cypripedium acaule, the stemless lady's slipper, may be the plant referred to with such enthusiasm by "Willie" Osler in his letter of 1867.

dropsy. Osler had obtained a packet of Withering's correspondence and planned to present his discoveries to the group. ${ }^{5}$

Did Osler exhibit any continuing interests in field botany after his youthful collecting days along the Humber? My review of Bibliotheca Osleriana, ${ }^{6}$ a list of 7783 texts and papers held in Osler's personal library, revealed no titles on botany or natural history to suggest an active interest in anything but the history of famous physician-naturalists. This supports the contention of Osler's biographer, Harvey Cushing, that, 
PINK OR STEMLESS LADY'S SLIPPER. MOCCASIN FLOWER. CYPRIPEDIUM ACAULE (ORCHIS FAMILY)

WEIRDLY beautiful, this plant is becoming alarmingly rare in settled neighbourhoods. Like its cousin, the yellow lady's slipper, it is too shy a plant to thrive near the haunts of men. In the shades of primitive forests, in deep mountain ravines, where the traffic and turmoil of the world are yet afar, it finds a fit setting for its wild grace and loveliness... The specific name, acaule, alludes to the apparently stemless habit of the plant. It would seem more appropriate to call this forest plant "moccasin flower", than "lady's slipper".

Excerpt from The Wildflowers of Canada (1908). Much of this book used illustrations and text from The Wildflowers of America, first published in 1894.

Reprinted with permission from Algrove Publishing Limited (Classic Reprint Series)

"Botany and its allied sciences had no claim on him except through his interest in their historical aspects." ${ }^{4}$ However, Osler lent his first editions of Dioscorides (De Materia Medica) and Theophrastus (On the History of Plants and Causes of Plants) to an exhibition on the Early History of Botany presented by the Botanical Society of the British Isles. He also procured and donated copies of 17 th and I8th century botanical correspondence to the Botanical Society as well. Upon Osler's death, G. Claridge Druce, FRS, the curator of Oxford University's herbarium, published a several-page obituary in a Report of the Ashmolean Natural History Society. ${ }^{5}$

During my first year of medical school, I also encountered a letter of advice from another medical icon, Albert Schweitzer. In 1948 Schweitzer wrote these words of advice to pre-med student William Larimer Mellon.

At the beginning of your studies, concentrate on the essentials: anatomy and physiology. As for zoology and botany, only learn what you need in order to pass your exams. I, myself, made the mistake of getting too deeply involved in these two subjects. ${ }^{7}$

There certainly is evidence that young Schweitzer was well versed in botany. In his autobiography, Schweitzer wrote that the

study of the natural sciences brought me even more than the increase of knowledge I had longed for. It was to me a spiritual experience. ... Through my study of ... botany ... I became more than ever conscious to what an extent truth in thought is justified and necessary, side by side with the truth which is merely established by the facts. ${ }^{8}$
Regarding the notion that natural medicines are somehow safer than manmade medicines, Schweitzer wrote:

Of the roots, bark, and leaves which the natives [of Gabon] use for all sorts of diseases, many have the peculiarity of irritating the kidneys severely, others of attacking the heart. Some of them, if given in excessive quantities, endanger life itself. ... Europeans who let themselves be treated with medicines used by the natives, paying for this sometimes a heavy penalty, are not so few in number as one would like to think. ${ }^{9}$

Schweitzer's caution may arise from his pharmacology training under Oswald Schmiedeberg at University of Strasbourg from I905-I9II. Schmiedeberg, considered the founder of modern pharmacology, pushed materia medica out of the medical curriculum in favour of a more analytic approach to pharmacology.

Schmiedeberg's move away from materia medica also influenced the Johns Hopkins Medical School during the Osler era. Another pupil of Schmiedeberg's (although much earlier than Schweitzer) was John J. Abel, an American who transformed the field of therapeutics from materia medica into the experimentally-based science of pharmacology. After studying with Schmiedeberg in the 1880 s, Abel established a pharmacology department at the University of Michigan in I89I, and later did the same under Osler at Johns Hopkins. At Hopkins, Abel's title was Professor of Pharmacology, the first time in the United States that materia medica was not part of the job description. ${ }^{10}$
Historically, the field of medicine has been inextricably allied with the discipline of botany, nevertheless the subject of medical botany has been discarded from the modern medical education. With the recent rise of alternative medicine in North America has come the call for physicians to become more aware of the roles of plants in medicine. ${ }^{11}$ Whether to learn the beneficial effects or the toxic effects of herbal preparations, there is once again a place for some instruction in botany for medical students. Evidence indicates that Osler and Schweitzer, two icons of modern medicine, knew their plants and valued the discipline of natural history. Even with today's surfeit of medical information, physicians will still benefit from the understanding and appreciation of the natural world around them.

\section{Scott A. Norton}

Dermatology Department

Uniformed Services University

of the Health Sciences

Bethseda, Md.

Acknowledgements: Jenny Bull and Dr. Tim Dickinson from the Green Plant Herbarium at the Royal Ontario Museum in Toronto provided valuable information on the orchids of the Humber Valley.

\section{REFERENCES}

I. Bliss M. William Osler: a life in medicine. Oxford: Oxford University Press; 1999.

2. Osler W. The evolution of modern medicine. New Haven: Yale University Press; 1923.

3. Porter R. The greatest benefit to mankind: a medical history of humanity from antiquity to the present. New York: WW Norton; 1997.

4. Cushing H. The life of Sir William Osler. Oxford: Clarendon Press; 1926.

5. Druce GC. Obituary: Sir William Osler. Rep Botanical Soc Exchange Club Br Isles I920;5:622-5.

6. Osler W. Bibliotheca Osleriana: a catalogue of books illustrating the history of medicine and science. Montreal: McGill-Queen's University Press; 1969.

7. Schweitzer A. Brothers in spirit: the correspondence of Albert Schweitzer and William Larimer Mellon, Jr. Syracuse: Syracuse University Press; 1996.

8. Schweitzer A. My life and thought: an autobiography. London: George Allen \& Unwin; 1933

9. Schweitzer A. On the edge of the primeval forest \& more from the primeval forest. New York: Macmillan; 1948.

Io. Parascandola J. The development of American pharmacology: John J Abel and the shaping of a discipline. Baltimore: Johns Hopkins Univ Press; I992.

II. Kemper KJ, Amata-Kynvi A, Sanghavi D, et al. Randomized trial of an internet curriculum on herbs and other dietary supplements for health care professionals. Acad Med 2002; 77:882-9. 